\title{
A Questionnaire Survey on the Sense of Educational and Social Equities among College Students in China
}

\author{
https://doi.org/10.3991/ijet.v15i14.15357 \\ Xiaolei Wang, Junchen Wang \\ Northeastern University at Qinhuangdao, Qinhuangdao, China \\ Zengxin $\mathrm{Li}\left({ }^{\square}\right)$ \\ Qinhuangdao Vocational and Technical College, Qinhuangdao, China \\ leezengxin@126.com
}

\begin{abstract}
The sense of equity reflects how fair a domain is as evaluated by those engaging in that domain. It is very meaningful to explore the sense of equity among college students, which are a special group of people. This study carried out a questionnaire survey on the sense of equity among 982 college students in China, from the perspectives of educational equity and social equity. The questions were validated by the $27 / 73$ quantile method, and the survey results were analyzed through one-way analysis of variance (one-way ANOVA). The results showed that the college students could evaluate the sense of equity rather accurately and generally had a higher sense of equity, but failed to sense the social outcome equity well; their sense of social equity was lower than the sense of educational equity; the sense of equity varied between college students in different majors: the science majors had a lower sense of equity than those majoring in liberal arts; some college students had a misunderstanding of equity.
\end{abstract}

Keywords-College students; sense of equity; educational equity; social equity

\section{Introduction}

Ever since the creation of organization and society, people's cognition of equity has been improved continuously with the development of social economy, and it has also promoted the constant evolution and innovation of the equity system. Contemporary college students are mostly the generation born after 1995 or 2000. During the formation period of their values, the social economy in China developed rapidly, the material conditions were continuously enriched, and information dissemination was fast and extensive, the multiculturalism has impacted the values of college students and provided them with more value options. The sense of equity is inextricably linked to a person's world outlook, outlook on life, and values. College students generally have a good ability to accept new things and a strong sense of independence, however, they are quite emotional and have a poor judgement, and sometimes their cognition is biased. 
College students' sense of equity is mainly manifested in two dimensions: educational equity and social equity. Educational equity refers to the fairness and protection of citizens' basic rights in education, that is, to ensure that personal and social factors won't hinder one reaching the education level as long as one's ability permits, and that all social members could receive the fundamental level or minimum standard level education. The sense of educational equity is a citizen's evaluation and attitude of the educational opportunities, resources and fairness he/she has received and perceived. Social equity is conditional, it focuses on the fairness of citizens in basic rights. The sense of social equity is a citizen's evaluation and attitude of the current situation of social justice, it's determined by two aspects: the objective social structure and the subjective psychological experience. Based on this, this paper attempts to investigate the sense of equity among college students from the two dimensions of educational equity and social equity, so as to find out existing problems and propose effective countermeasures.

The issue of equity has always been a research hotspot in the academic circle. Based on management, law and psychology theories, many scholars have conducted in-depth research on equity principles, people's equity sense and equity behavior in different cultures from different perspectives, as shown below:

In terms of the studies on organization and management equity, scholars mainly investigated the relationship between the equity sense of the members in the organization and their behavior, and its intermediary or moderating variables. Collins [1] found that employees' turnover intention has a moderating effect on the relationship between their sense of procedure fairness and their performance, and he emphasized that managers of the organization should pay close attention to the employees' possible turnover intention. Poon [2] studied the relationship between procedure equity, distribution equity and employees' turnover tendency. He believes that, due to the influence of procedure equity, emotional commitment plays different intermediary roles between distribution equity and the employees' turnover tendency. Yeol [3] conducted research on the three dimensions of distribution equity, interaction equity and procedure equity, and found that the trust on the organization mediates the relationship between organization equity and member behavior. Moon [4] took civil servants as research objects and explored the correlation between the sense of organization justice, the turnover rate and the performance. Herr et al. [5] analyzed the relationship between the organization justice, the employees' work attitude, and their physical and mental health conditions. And he believed that a fair atmosphere in the organization is related to the employees' work attitude and health status. Nazir et al. [6] noted that organization justice, organizational culture, and organizational support have significant influence on employees' emotional identity and innovative behavior. Blouch and Azeem [7] noted that organization justice can moderate the relationship between employees' diverse perception and the organization's performance. Sahoo [8] examined the influence of organization justice and conflict management on the relationship between employees. And he believed that the trust on the organization is an intermediary variable between the two. Shoaib and Baruch [9] believed that organization justice is a moderating variable of the relationship between the possibility of employees' deviant behavior and the incentive effect. 
In terms of the studies on the procedural equity, scholars pay more attention to the correlation between procedural equity and the public's acceptance of government decisions and judicial results. Visschers [10] investigated the public's acceptance of new energy policies. And he believes that the outcome fairness has a significant impact on the acceptance of the decisions, while its impact on procedural equity is limited. Van Craen and Skogan [11] analyzed the relationship between procedural equity and the legitimacy of police affairs, their research showed that the public's sense of procedural equity is directly related to the procedures and the trust of the citizens. Whitton et al. [12] studied the development of shale gas governance decisions in the United States and the United Kingdom, and concluded that social justice and procedural justice are relatively lacking in governance decisions. Magalhaes and AguiarConraria [13] believed that the interaction between the decision-making process and the decision-making results has an impact on citizens' policy acceptance. Esaiasson et al. [14] questioned that people's acceptance of decisions is affected by procedural equity. And they believed that result preference is the main determinant of citizens' acceptance to a decision. Niesiobedzka and Kolodziej [15] investigated the influencing factors of citizens' acceptance to tax authorities' decisions. And they also believed that citizens' acceptance of policies depends only on the result preferences and has nothing to do with procedural fairness.

In terms of the studies on the equity from the perspective of psychology, scholars tend to use psychological experiments to research people's sense of equity and its influence. Geraci and Surian [16] observed babies with an average age of 16 months and found that they are more concerned about the distribution results. Sloane [17] investigated babies' expectations for resource allocation. And he believed that 2-yearold babies already have fairness-related expectations. Robbins et al. [18] found that the sense of inequity is related to citizens' physical and mental health indicators. Shaw et al. [19] conducted an allocation experiment on children aged between 6 and11 years old, and found that, as they grow older, children will pay more attention to others' evaluations and therefore behave more fairly. Maier and Priest [20] noted that there is a correlation between couples' sense of equity in their relationship, their marital conflict and the depression. Starmans et al. [21] emphasized the difference between equity and equality. And they believed that people prefer equitable distribution to equal distribution. McAuliffe et al. [22] studied the influence of supervise behavior on the favorable distribution of children aged 6-9, and the results showed that the supervise behavior of the peers would affect their acceptance of favorable distribution.

Drawing on the existing research results, our study surveyed college students in several Chinese universities using online questionnaires. This paper attempts to enrich the empirical research results of college students' sense of equity in terms of organization equity, so as to understand the current status of college students' sense of equity and propose targeted countermeasures for equity education. 


\section{Research Design}

\subsection{Research object and purpose}

In this study, Chinese college students were selected as the sampling group to conduct an in-depth investigation on their sense of equity. The subjects were in the education stage and about to enter the society. They had already formed a basic concept of equity and relative stable cognition about equities in social phenomena.

This research took educational equity and social equity as research content, and aimed to investigate the influence of demographic statistical variables on college students' sense of equity through questionnaire survey, so as to give a reasonable analysis of college students' sense of equity and explore directions for the equity education of college students.

\subsection{Research method}

Questionnaires were issued online to investigate the current status of college students' sense of equity, for each account, the questionnaire could only be filled once, all questions were required questions, and the questionnaires mustn't have blank answers or filled repeatedly by a same respondent. A total of 982 questionnaires were recovered, wherein 906 were valid, and the effective rate was $92.261 \%$.

The majority of respondents were college students from the Northeastern University at Qinhuangdao in China, and some were from other Chinese colleges or universities. The proportions of science majors (science, engineering, agriculture, medicine) and liberal arts majors (philosophy, economics, law, pedagogy, literature, history, management) were basically the same, wherein most respondents had a clear and accurate understanding of equity, however, some respondents only had a vague cognition of equity, these situations can basically reflect college students' cognition of equity. The composition of the samples is shown in Table 1.

\subsection{Research tools and statistical analysis}

Drawing on existing literatures, this study adopted questionnaire survey to investigate college students' sense of equity, and conducted semi-structured interviews with 24 college students to form key information, and the Questionnaire for College Students' Sense of Equity was compiled. The questionnaire was mainly composed of two scales, for the scale of the sense of educational equity, there were 3 dimensions and 12 items; as for the scale of the sense of social equity, there were 3 dimensions and 15 items. The scales were 5-point Likert scale, with options 1-5 respectively representing strongly disagree, disagree, neutral, agree, and strongly agree. There were no reversescored items. Respondents with higher scores have a higher-level sense of equity, and respondents with lower scores have a lower-level sense of equity.

The IBM SPSS Statistics 26.0 software was used in the study to analyze the valid data collected. 
Table 1. Composition of samples

\begin{tabular}{|c|c|c|c|}
\hline Variables & Categories & Frequency & Percentage (\%) \\
\hline \multirow{2}{*}{ Gender } & Male & 558 & 61.6 \\
\hline & Female & 348 & 38.4 \\
\hline \multirow{5}{*}{ Grade } & Freshman year & 166 & 18.3 \\
\hline & Sophomore year & 330 & 36.4 \\
\hline & Junior year & 280 & 30.9 \\
\hline & Senior year & 122 & 13.5 \\
\hline & Postgraduate & 8 & 0.9 \\
\hline \multirow{11}{*}{ Major } & Philosophy & 10 & 1.1 \\
\hline & Economics & 150 & 16.6 \\
\hline & Law & 40 & 4.4 \\
\hline & Pedagogy & 40 & 4.4 \\
\hline & \begin{tabular}{|l|} 
Literature \\
\end{tabular} & 26 & 2.9 \\
\hline & History & 8 & 0.9 \\
\hline & Science & 46 & 5.1 \\
\hline & Engineering & 440 & 48.6 \\
\hline & \begin{tabular}{|l|} 
Agriculture \\
\end{tabular} & 2 & 0.2 \\
\hline & Medicine & 34 & 3.8 \\
\hline & Management & 110 & 12.1 \\
\hline \multirow{3}{*}{$\begin{array}{l}\text { Is there any difference } \\
\text { among equity, justice and } \\
\text { equality? }\end{array}$} & Yes & 748 & 82.6 \\
\hline & No & 94 & 10.4 \\
\hline & Not clear & 64 & 7.1 \\
\hline \multirow{3}{*}{$\begin{array}{l}\text { Is equity absolute or rela- } \\
\text { tive? }\end{array}$} & Absolute & 50 & 5.5 \\
\hline & Relative & 830 & 91.6 \\
\hline & Not clear & 26 & 2.9 \\
\hline
\end{tabular}

\section{Result Analysis}

\subsection{Statistical analysis of college students' sense of educational equity}

Scale reliability analysis and exploratory factor analysis: The 27/73 quantile method was adopted for correlation test, question test, and $\alpha$ test to analyze each item (A1A12) in the educational equity sense scale. The Pearson correlation value of each item was between 0.229 and $0.697, \mathrm{p}<0.01$, the correlation was significant. According to the data in Table 2, the degree of distinction of each question was significant, the CITC values were all greater than 0.45 . There was no need to delete any item; the Cronbach $\alpha$ value was 0.893 , and the reliability was good.

Principal component analysis (PCA) and maximum variance method were adopted to divide dimensions of questions with multiple loads in terms of content. And the results are shown in Table 3. 
Table 2. Results of question analysis and $\alpha$ test of educational equity sense scale ${ }^{*} \mathrm{p}<0.05 * *$ $\mathrm{p}<0.01)$

\begin{tabular}{|l|c|c|c|c|c|}
\hline & \multicolumn{2}{|c|}{ Groups (Mean \pm standard deviation) } & \multirow{2}{*}{ C.R. value } & p & \multirow{2}{*}{ CITC } \\
\cline { 2 - 3 } & Low-score group $(\mathrm{n}=242)$ & High-score group $(\mathrm{n}=244)$ & & & \\
\hline A1 & $3.00 \pm 0.96$ & $4.39 \pm 0.67$ & -13.035 & $0.000^{* *}$ & 0.518 \\
\hline A2 & $2.77 \pm 1.00$ & $4.39 \pm 0.58$ & -15.481 & $0.000^{* *}$ & 0.668 \\
\hline A3 & $2.74 \pm 0.92$ & $4.26 \pm 0.71$ & -14.391 & $0.000^{* *}$ & 0.664 \\
\hline A4 & $2.64 \pm 1.04$ & $4.34 \pm 0.72$ & -14.774 & $0.000^{* *}$ & 0.559 \\
\hline A5 & $2.45 \pm 0.93$ & $4.32 \pm 0.61$ & -18.486 & $0.000^{* *}$ & 0.712 \\
\hline A6 & $2.55 \pm 0.95$ & $4.30 \pm 0.60$ & -17.234 & $0.000^{* *}$ & 0.658 \\
\hline A7 & $2.08 \pm 0.84$ & $4.11 \pm 0.88$ & -18.349 & $0.000^{* *}$ & 0.637 \\
\hline A8 & $2.17 \pm 0.86$ & $4.11 \pm 0.72$ & -19.053 & $0.000^{* *}$ & 0.688 \\
\hline A9 & $3.13 \pm 1.26$ & $4.48 \pm 0.75$ & -10.092 & $0.000^{* *}$ & 0.462 \\
\hline A10 & $2.93 \pm 1.07$ & $4.58 \pm 0.57$ & -14.987 & $0.000^{* *}$ & 0.601 \\
\hline A11 & $3.10 \pm 1.02$ & $4.49 \pm 0.75$ & -12.105 & $0.000^{* *}$ & 0.55 \\
\hline A12 & $3.25 \pm 1.02$ & $4.48 \pm 0.58$ & -11.614 & $0.000^{* *}$ & 0.524 \\
\hline Standardized Cronbach $\alpha$ coefficient: 0.893 & & & \\
\hline
\end{tabular}

Table 3. Exploratory factor analysis results of educational equity sense scale

\begin{tabular}{|c|c|c|c|}
\hline \multirow[b]{2}{*}{ Questions } & \multicolumn{3}{|c|}{ Factors } \\
\hline & $\begin{array}{c}\text { Education } \\
\text { opportunity } \\
\text { equity }\end{array}$ & $\begin{array}{c}\text { Education } \\
\text { procedure } \\
\text { equity }\end{array}$ & $\begin{array}{c}\text { Education } \\
\text { outcome } \\
\text { equity }\end{array}$ \\
\hline A1: Citizens have equal access to schools & 0.832 & & \\
\hline $\begin{array}{l}\text { A2: Schools can provide students with a fair competition envi- } \\
\text { ronment }\end{array}$ & 0.595 & & \\
\hline $\begin{array}{l}\text { A3: Current student financial aid system is reasonable and effec- } \\
\text { tive }\end{array}$ & 0.458 & & \\
\hline A4: Fair enrollment for students from impoverished areas & 0.41 & & \\
\hline $\begin{array}{l}\text { A7: School teaching pays attention to teaching students according } \\
\text { to their aptitude }\end{array}$ & & 0.841 & \\
\hline $\begin{array}{l}\text { A8: School evaluation indicators can reflect the students' com- } \\
\text { prehensive ability }\end{array}$ & & 0.811 & \\
\hline $\begin{array}{l}\text { A5: School reward mechanism and evaluation system are sound } \\
\text { and complete }\end{array}$ & & 0.697 & \\
\hline $\begin{array}{l}\text { A6: School reward mechanism and evaluation procedure are } \\
\text { transparent }\end{array}$ & & 0.64 & \\
\hline $\begin{array}{l}\text { A11: Students' academic performance and development status are } \\
\text { linked to their personal abilities }\end{array}$ & & & 0.837 \\
\hline $\begin{array}{l}\text { A9: In China, the distinctions of ordinary colleges and the uni- } \\
\text { versities under the } 985 \text { project and } 211 \text { projects are equitable. }\end{array}$ & & & 0.694 \\
\hline $\begin{array}{l}\text { A10: Students' academic performance and development status are } \\
\text { linked to their efforts }\end{array}$ & & & 0.694 \\
\hline $\begin{array}{l}\text { A12: Students' employment status is linked to their educational } \\
\text { level }\end{array}$ & & & 0.665 \\
\hline KMO & 0.912 & & \\
\hline Chi-square value of Bartlett test of sphericity & 2311.032 & & \\
\hline Eigenvalue & 3.306 & 2.511 & 1.789 \\
\hline Percentage of explained variance (\%) & 27.55 & 20.921 & 14.909 \\
\hline Cumulative explained variance percentage (\%) & 27.55 & 48.471 & 63.38 \\
\hline
\end{tabular}


The KMO value was 0.912 , which was greater than 0.8 , and the data in the educational equity sense scale was quite suitable for factor analysis. After the factors were extracted, the obtained cumulative percentage of explained variance was $63.380 \%$, which was greater than $60 \%$, and the information amount of each question could be effectively extracted. The extracted factors were named education opportunity equity, education procedure equity, and education outcome equity.

Differences in demographic variables of college students' sense of educational equity: One-Way ANOVA was adopted to study the differences in education opportunity equity, education procedure equity, and education outcome equity (the value of each dimension was the average score of all questions within the dimension) in terms of gender, grade and major. The survey results showed that, in terms of gender and grade, the p-values of education opportunity equity, education procedure equity, and education outcome equity were all greater than 0.1 , there's no significant difference; in terms of major, the p-value of education outcome equity was greater than 0.1 , showing no significant difference, while the p-values of education opportunity equity and education procedure equity were 0.014 and 0.001 , respectively, showing significant differences. Therefore, in terms of major, the education opportunity equity and education procedure equity were subject to DunCan's Multiple comparison again and the obtained results are shown in Table 4.

Table 4. DunCan's Multiple comparison results of education opportunity equity and education procedure equity in terms of major $(* \mathrm{p}<0.05 * * \mathrm{p}<0.01)$

\begin{tabular}{|l|l|c|c|c|c|c|}
\hline & (I) Name & (J) Name & (I) Mean & $\begin{array}{c}\text { (J) } \\
\text { Mean }\end{array}$ & Difference (I-J) & p \\
\hline Education opportunity equity & Natural sciences & Liberal arts & 3.508 & 3.684 & -0.176 & $0.014 *$ \\
\hline Education procedure equity & Natural sciences & Liberal arts & 3.286 & 3.532 & -0.245 & $0.001 * *$ \\
\hline
\end{tabular}

It can be seen from the table that, in terms of major, education opportunity equity showed a 0.05 significance level $(F=6.120, p=0.014)$, and the average value of the natural sciences (3.508) was significantly lower than that of the humanities and social sciences (3.684); the education procedure equity showed a 0.01 significance level $(\mathrm{F}=$ $10.322, \mathrm{p}=0.001)$, and the average value of the natural sciences (3.286) was significantly lower than that of the liberal arts (3.532), indicating that for college students majored in natural sciences, their sense of education opportunity equity and education procedure equity was significantly lower than those who majored in liberal arts.

Therefore, college students' sense of education equity had differences in terms of major, but it didn't show significant difference in terms of gender and grade. This situation was in line with the current situation of China's education system which divided majors into natural sciences and liberal arts. Students of different discipline divisions received different educational content since high school. During the formation and development periods of students' outlooks on life and values, due the different educational contents, methods, and emphases they received and learnt, they would have different perceptions of education equity conditions.

The accuracy of college students' sense of educational equity: The mean value of each dimension and demographic variables were taken as independent variables, 
and the average score of educational equity (the average value of the scores from the first time and the second time) was taken as the dependent variable for stepwise regression analysis. After automatic model identification, at last, three items of the average value of education opportunity equity dimension, the average value of education procedure equity dimension, and the average value of education outcome equity dimension were retained, and the R2 value was 0.399 , which could explain the reason for the change in the average score $39.9 \%$ of the sense of educational equity.

The model had passed the F-test $(\mathrm{F}=99.196, \mathrm{p}=0.000<0.05)$, and the formula of the model was: average score of educational equity $=0.829+0.441 *$ mean value of education opportunity equity dimension $+0.175 *$ mean value of education procedure equity dimension $+0.134 *$ mean value of education outcome equity dimension. In addition, the test on the multicollinearity of the model found that, in the model, the VIF values were all less than 5 , so there's no collinearity problem; the D-W value was near 2, so there was no autocorrelation, namely there was no correlation between the sample data, and the model was good.

The mean values of the three dimensions had a significant positive impact on the average score of educational equity. Therefore, college students' sense of educational equity was basically consistent with the evaluation results, indicating that when judging whether an educational phenomenon was equitable or not, college students could consider comprehensively rather than being completely influenced by personal emotions.

\subsection{Statistical analysis of college students' sense of social equity}

Scale reliability analysis and exploratory factor analysis: The 27/73 quantile method was adopted for correlation test, question test, and $\alpha$ test to analyze each item (B1-B15) in the social equity sense scale. The Pearson correlation value of each item was between 0.291 and 0.820. According to the data in Table 5, the C.R. value of B14 was relatively low, the degree of distinction of this item was not good, its CITC value was less than 0.5 , so this item was deleted. The remaining items had a good degree of distinction, and the correlations were significant; after item B14 was deleted, the Cronbach $\alpha$ value of the scale changed from the original 0.939 to 0.940 , and its reliability was good. 
Table 5. Results of question analysis and $\alpha$ test of social equity sense scale $(* \mathrm{p}<0.05 * *$ $\mathrm{p}<0.01)$

\begin{tabular}{|c|c|c|c|c|c|c|}
\hline & $\begin{array}{r}\text { Groups (Mean } \pm s \\
\text { tion }\end{array}$ & andard devia- & G D & & CTTC & \\
\hline & $\begin{array}{c}\text { Low-score group } \\
(n=214)\end{array}$ & $\begin{array}{c}\text { High-score } \\
\text { group }(n=214)\end{array}$ & C.K. value & $\mathbf{P}$ & CHIC & $\begin{array}{l}\alpha \text { coefficient after } \\
\text { question deletion }\end{array}$ \\
\hline B1 & $2.74 \pm 1.05$ & $4.46 \pm 0.57$ & -14.892 & $0.000 * *$ & 0.639 & 0.937 \\
\hline B2 & $2.11 \pm 0.94$ & $4.32 \pm 0.59$ & -20.457 & $0.000 * *$ & 0.703 & 0.935 \\
\hline B3 & $1.84 \pm 0.89$ & $4.21 \pm 0.74$ & -21.189 & $0.000 * *$ & 0.723 & 0.934 \\
\hline B4 & $1.42 \pm 0.63$ & $4.23 \pm 0.69$ & -31.027 & $0.000 * *$ & 0.756 & 0.934 \\
\hline \begin{tabular}{|l|} 
B5 \\
\end{tabular} & $2.31 \pm 0.82$ & $4.40 \pm 0.66$ & -20.652 & $0.000 * *$ & 0.757 & 0.934 \\
\hline B6 & $2.22 \pm 0.80$ & $4.32 \pm 0.58$ & -21.882 & 0.000 ** & 0.764 & 0.933 \\
\hline \begin{tabular}{|l|} 
B7 \\
\end{tabular} & $2.85 \pm 0.94$ & $4.36 \pm 0.69$ & -13.349 & $0.000 * *$ & 0.634 & 0.937 \\
\hline B8 & $2.21 \pm 0.88$ & $3.97 \pm 0.69$ & -16.227 & $0.000 * *$ & 0.634 & 0.937 \\
\hline B9 & $1.82 \pm 0.75$ & $4.13 \pm 0.73$ & -22.846 & $0.000 * *$ & 0.742 & 0.934 \\
\hline B10 & $2.38 \pm 0.91$ & $4.22 \pm 0.72$ & -16.46 & $0.000^{* *}$ & 0.642 & 0.936 \\
\hline B11 & $1.42 \pm 0.55$ & $4.05 \pm 0.71$ & -30.364 & $0.000^{* *}$ & 0.785 & 0.933 \\
\hline B12 & $1.35 \pm 0.53$ & $3.86 \pm 0.83$ & -26.368 & $0.000^{* *}$ & 0.744 & 0.934 \\
\hline B13 & $1.96 \pm 0.78$ & $4.14 \pm 0.77$ & -20.599 & $0.000^{* *}$ & 0.699 & 0.935 \\
\hline B14 & $2.93 \pm 1.04$ & $4.19 \pm 0.69$ & -10.44 & $0.000^{* *}$ & 0.481 & 0.94 \\
\hline B15 & $2.25 \pm 0.98$ & $4.17 \pm 0.64$ & -16.935 & $0.000^{* *}$ & 0.623 & 0.937 \\
\hline
\end{tabular}

After B14 was deleted, PCA and maximum variance method were adopted to extract 3 factors and divide dimensions of questions with multiple loads in terms of content. B9 was not consistent with the expected dimension division because it had multiple meanings, so it was deleted as well. After the deletion of B14 and B9, the reliability and validity test results obtained are shown in Table 6.

The Cronbach $\alpha$ value of the scale changed to 0.934 , which was greater than 0.8 , and the reliability was good. The KMO value was 0.939 , also greater than 0.8 , so the data in the social equity sense scale was very suitable for factor analysis. After the factors were extracted, the cumulative explained variance percentage obtained was $69.467 \%$, which was greater than $60 \%$. The information amount of each question can be effectively extracted, and the extracted factors were respectively named as social opportunity equity, social procedure equity, and social outcome equity. 
Table 6. Reliability and validity test results of the social equity sense scale after deleting questions B14 and B9

\begin{tabular}{|c|c|c|c|}
\hline \multirow[b]{2}{*}{ Questions } & \multicolumn{3}{|c|}{ Factors } \\
\hline & $\begin{array}{c}\text { Social opportunity } \\
\text { equity }\end{array}$ & $\begin{array}{c}\text { Social procedure } \\
\text { equity }\end{array}$ & $\begin{array}{c}\text { Social outcome } \\
\text { equity }\end{array}$ \\
\hline $\begin{array}{l}\text { B1: Citizens have equal rights in receiving } \\
\text { education }\end{array}$ & 0.798 & & \\
\hline $\begin{array}{l}\text { B2: Citizens have equal rights in employ- } \\
\text { ment opportunities }\end{array}$ & 0.746 & & \\
\hline $\begin{array}{l}\text { B3: There is no difference in status between } \\
\text { men and women }\end{array}$ & 0.608 & & \\
\hline $\begin{array}{l}\text { B5: National policies concerning benefit } \\
\text { distribution are fair and reasonable } \\
\end{array}$ & 0.585 & & \\
\hline B4: All social classes have equal status & 0.506 & & \\
\hline $\begin{array}{l}\text { B7: The laws can protect citizens' legal } \\
\text { rights }\end{array}$ & & 0.71 & \\
\hline $\begin{array}{l}\text { B8: Government officials are honest and } \\
\text { upright }\end{array}$ & & 0.699 & \\
\hline $\begin{array}{l}\text { B9: The society takes more care of vulnera- } \\
\text { ble groups }\end{array}$ & & 0.621 & \\
\hline $\begin{array}{l}\text { B6: Citizens' reasonable demands are } \\
\text { valued by the government }\end{array}$ & & 0.516 & \\
\hline $\begin{array}{l}\text { B11: The gap between rich and poor is } \\
\text { small }\end{array}$ & & & 0.851 \\
\hline $\begin{array}{l}\text { B10: The development gap between differ- } \\
\text { ent regions is small }\end{array}$ & & & 0.828 \\
\hline B12: Equal pay for equal work & & & 0.658 \\
\hline $\begin{array}{l}\text { B13: The personal income can reflect one's } \\
\text { social value }\end{array}$ & & & 0.422 \\
\hline Standardized Cronbach $\alpha$ coefficient & 0.934 & & \\
\hline KMO & 0.939 & & \\
\hline $\begin{array}{l}\text { Chi-square value of Bartlett test of spherici- } \\
\text { ty }\end{array}$ & 3712.706 & & \\
\hline Eigenvalue & 3.497 & 3.239 & 2.295 \\
\hline Percentage of explained variance (\%) & 26.901 & 24.912 & 17.654 \\
\hline $\begin{array}{l}\text { Cumulative explained variance percentage } \\
(\%)\end{array}$ & 26.901 & 51.813 & 69.467 \\
\hline
\end{tabular}

Differences in demographic statistics of college students' sense of social equity: One-Way ANOVA was adopted to study the differences in social opportunity equity, social procedure equity, and social outcome equity (the value of each dimension was the average score of all questions within the dimension) in terms of gender, grade and major. The survey results showed that, in terms of gender, the p-values of social opportunity equity, social procedure equity, and social outcome equity were all greater than 0.05 , showing no significant difference; in terms of grade, the p-values of social opportunity equity and social procedure equity were 0.088 and 0.119 , respectively, also showing no significant difference, while the social outcome equity showed a 0.05 significance level $(\mathrm{F}=3.073, \mathrm{p}=0.016)$, that is, for respondents of different grades, there're significant differences in terms of social outcome equity. 
In terms of major, the p-values of social opportunity equity, social procedure equity, and social outcome equity were all smaller than 0.01 , showing significant differences with a 0.01 significance level, then they were subject to DunCan's Multiple comparison again and the obtained results are shown in Table 7.

Table 7. DunCan's Multiple comparison results of the three dimensions of social equity in terms of major $(* \mathrm{p}<0.05 * * \mathrm{p}<0.01)$

\begin{tabular}{|l|c|c|c|c|c|c|}
\hline & (I) Name & (J) Name & (I) Mean & (J) Mean & Difference (I-J) & p \\
\hline Social opportunity equity & Natural sciences & Liberal arts & 3.179 & 3.466 & -0.287 & $0.000^{* *}$ \\
\hline Social procedure equity & Natural sciences & Liberal arts & 3.256 & 3.449 & -0.194 & $0.008 * *$ \\
\hline Social outcome equity & Natural sciences & Liberal arts & 2.646 & 3.099 & -0.453 & $0.000 * *$ \\
\hline
\end{tabular}

It can be found that, in terms of major, college students had significant differences in the sense of social equity. The science majors' sense of social equity was generally lower than liberal arts students; in terms of social outcome equity dimension, there were significant differences among college students in different grades; but there was no significant difference among college students of different genders. This indicated that, with the increase of grades and employment pressure, college students would have deeper understandings of the society, therefore their cognition of unfair phenomena in the society would become more profound.

The accuracy of college students' sense of social equity: The mean value of each dimension and demographic variables were taken as independent variables, and the average score of social equity (the average value of the scores from the first time and the second time) was taken as the dependent variable for stepwise regression analysis. After automatic model identification, at last, two items of the average value of social opportunity equity dimension and the average value of social procedure equity dimension were retained in the model, and the R2 value was 0.360 , which could explain the reason for the change in the average score $36.0 \%$ of the sense of social equity.

The model had passed the F-test $(F=126.372, p=0.000<0.05)$, and the formula of the model was: average score of the sense of social equity $=0.931+0.257 *$ mean value of social opportunity equity dimension $+0.402 *$ mean value of social procedure equity dimension. In addition, the test on the multicollinearity of the model found that, in the model, the VIF values were all less than 5, indicating that there's no collinearity problem; the D-W value was near 2, so there was no autocorrelation, namely there was no correlation between the sample data, and the model was good.

The average values of the social opportunity equity dimension and social procedure equity dimension had a significant positive impact on the average score of social equity, while the average value of social outcome equity dimension did not have a relationship with the average score of social equity. The invisible employment pressure had forced college students to see many unfair phenomena in the society, so there's a deviation between their overall cognition of the sense of social equity and the evaluation results. 


\subsection{Statistics and comparison of college students' sense of equity}

The dimensions of college students' sense of educational and social equities were calculated and the results are shown in Table 8. From the data in the table we can see that, except that the score of social outcome equity dimension was lower than the midpoint score ( 3 points), the scores of the other dimensions were all higher than the midpoint score ( 3 points). Therefore, overall, college students had a higher equity sense level, but they had a sense of inequity in terms of social outcome.

Table 8. Statistical results of dimensions in the scales

\begin{tabular}{|l|c|c|c|}
\hline & M & SD & Var \\
\hline Education opportunity equity & 3.5822 & 0.75221 & 0.566 \\
\hline Education procedure equity & 3.3422 & 0.86933 & 0.756 \\
\hline Education outcome equity & 3.8698 & 0.75377 & 0.568 \\
\hline Social opportunity equity & 3.2062 & 0.90932 & 0.827 \\
\hline Social procedure equity & 3.3471 & 0.79472 & 0.632 \\
\hline Social outcome equity & 2.8377 & 0.93919 & 0.882 \\
\hline
\end{tabular}

Through the pairwise t-test, the differences in the cognition of educational equity and social equity, as well as the differences in the cognition of educational equity degree and social equity degree before and after filling the scales were studied as shown in Table 9.

The four groups of paired data all showed a 0.01-level difference $(\mathrm{p}<0.01)$. Since the differences of the first two pairs were negative and significant, compared with social equity conditions, college students were more approved of the educational equity conditions at present.

As for the results of the other two pairs, the differences were negative and significant, indicating that college students' psychological expectation of their sense of equity was lower than actual situation; after filling the scales, their recognition of educational equity degree and social equity degree had been improved. 
Table 9. Pairwise t-test results of the sense of educational equity and social equity of college students

\begin{tabular}{|c|c|c|c|c|c|}
\hline \multirow[t]{2}{*}{ Name } & \multicolumn{2}{|c|}{\begin{tabular}{|c|} 
Pairs (Mean value \pm standard devia- \\
tion)
\end{tabular}} & \multirow{2}{*}{$\begin{array}{c}\text { Difference (Pair 1- Pair } \\
\text { 2) }\end{array}$} & \multirow[t]{2}{*}{$\mathbf{t}$} & \multirow[t]{2}{*}{ p } \\
\hline & Pair 1 & Pair 2 & & & \\
\hline $\begin{array}{l}\text { Average value of social } \\
\text { equity sense scale } \\
\text { paired with }\end{array}$ & \multirow[t]{2}{*}{$3.17 \pm 0.79$} & \multirow[t]{2}{*}{$3.60 \pm 0.68$} & \multirow[t]{2}{*}{-0.43} & \multirow{2}{*}{18.045} & \multirow{2}{*}{$\begin{array}{c}0.000 * \\
*\end{array}$} \\
\hline $\begin{array}{l}\text { Average value of educa- } \\
\text { tional equity sense scale }\end{array}$ & & & & & \\
\hline $\begin{array}{l}\text { Average value of the } \\
\text { scores of social equity } \\
\text { sense } \\
\text { paired with } \\
\end{array}$ & \multirow[t]{2}{*}{$3.12 \pm 0.85$} & \multirow[t]{2}{*}{$3.51 \pm 0.83$} & \multirow[t]{2}{*}{-0.38} & \multirow{2}{*}{10.007} & \multirow{2}{*}{$\begin{array}{c}0.000 * \\
*\end{array}$} \\
\hline $\begin{array}{l}\text { Average value of the } \\
\text { scores of educational } \\
\text { equity sense }\end{array}$ & & & & & \\
\hline $\begin{array}{l}\text { Score of educational } \\
\text { equity degree for the } \\
\text { first time } \\
\text { paired with }\end{array}$ & \multirow[t]{2}{*}{$3.49 \pm 0.91$} & \multirow[t]{2}{*}{$3.52 \pm 0.86$} & \multirow[t]{2}{*}{-0.03} & \multirow[t]{2}{*}{-1.154} & \multirow[t]{2}{*}{$\begin{array}{c}0.000 * \\
*\end{array}$} \\
\hline $\begin{array}{l}\text { Score of educational } \\
\text { equity degree for the } \\
\text { second time }\end{array}$ & & & & & \\
\hline $\begin{array}{l}\text { Score of social equity } \\
\text { degree for the first time } \\
\text { paired with }\end{array}$ & \multirow{2}{*}{$3.04 \pm 0.94$} & \multirow{2}{*}{$3.21 \pm 0.90$} & \multirow{2}{*}{-0.17} & \multirow{2}{*}{-5.33} & \multirow{2}{*}{$\begin{array}{c}0.000^{*} \\
*\end{array}$} \\
\hline $\begin{array}{l}\text { Score of social equity } \\
\text { degree for the second } \\
\text { time }\end{array}$ & & & & & \\
\hline
\end{tabular}

\section{Conclusion}

Through the above analysis, it can be found that college students had a relative accurate estimation of their cognition situation of the sense of equity, they can reflect on the questions in the questionnaires and modify their cognition of the equity conditions. Overall, they had a higher-level sense of equity; their educational equity sense was generally higher than the social equity sense, but their cognition of social outcome equity was relatively poor; a few college students lacked the correct cognition of the distinction between the word "equity" and other vocabularies (about 17.5\%) and the relativity of equity (about $8.4 \%$ ); college students' sense of equity was related to their majors, natural science majors generally had a lower-level sense of equity than liberal arts majors.

Based on above summary, this paper believes that it's necessary to pay attention to the impact of education system reform and online media on college students' sense of equity; we should pay attention to the following aspects: constantly improve the education system and mechanisms, and make good use of online media to promote positive spirit; transform the traditional ideological and political education mode to make it more subtle and efficient; different ideological and political education methods 
concerning the idea of equity should be carried out according to the different majors in a targeted manner; strengthen compassionate care for impoverished students, and protect education equity.

\section{Acknowledgement}

The research is supported by the Social Science Research Foundation in Higher Education of Hebei Province of China in 2019 (Grant number: SZ19065).

\section{References}

[1] Collins, B. J., Mossholder, K. W., Taylor, S. G. (2012). Does process fairness affect job performance? It only matters if they plan to stay. Journal of Organizational Behavior, 33(7): 1007-1026. https://doi.org/10.1002/job.1779

[2] Poon, J. M. L. (2012). Distributive justice, procedural justice, affective commitment, and turnover intention: A mediation-moderation framework. Journal of Applied Social Psychology, 42(6): 1505-1532. https://doi.org/10.1111/j.1559-1816.2012.00910.x

[3] Yeol, J. S. (2016). Effects of organizational trust by employees in franchised Korean restaurants on the relationship between organizational justice and organizational citizenship behavior. International Journal of Tourism and Hospitality Research, 30(9): 191-205. https://doi.org/10.21298/IJTHR.2016.09.30.9.191

[4] Moon, K. K. (2017). Fairness at the organizational level: examining the effect of organizational justice climate on collective turnover rates and organizational performance. Public Personnel Management, 46(2): 118-143. https://doi.org/10.1177/009102601770261 $\underline{0}$

[5] Herr, R. M., Almer, C., Bosle, C., Fischer, J. E. (2020). Associations of changes in Organizational justice with job attitudes and health-findings from a prospective study using a matching-based difference-in-difference approach. International Journal of Behavioral Medicine, 27(1): 119-135. https://doi.org/10.1007/s12529-019-09841-z

[6] Nazir, S., Shafi, A., Atif, M. M., Qun, W., Abdullah, S. M. (2019). How organization justice and perceived organizational support facilitate employees' innovative behavior at work. Employee Relations, 41(6): 1288-1311. https://doi.org/10.1108/ER-01-2017-0007

[7] Blouch, R., Azeem, M. F. (2019). Effects of perceived diversity on perceived organizational performance Mediating role of perceived organizational justice. Employee Relations, 41(5): 1079-1097. https://doi.org/10.1108/ER-05-2018-0150

[8] Sahoo, R., Sahoo, C. K. Organizational justice, conflict management and employee relations the mediating role of climate of trust. International Journal of Manpower, 40(4): 783-799. https://doi.org/10.1108/IJM-12-2017-0342

[9] Shoaib, S., Baruch, Y. (2019). Deviant behavior in a moderated-mediation framework of incentives, organizational justice perception, and reward expectancy. Journal of Business Ethics, 157(3): 617-633. https://doi.org/10.1007/s10551-017-3651-y

[10] Visschers, V. H. M., Siegrist, M. (2012). Fair play in energy policy decisions: Procedural fairness, outcome fairness and acceptance of the decision to rebuild nuclear power plants. Energy Policy, (46): 292-300. https://doi.org/10.1016/j.enpol.2012.03.062

[11] Van Craen, M., Skogan, W. G. (2017). Achieving Fairness in Policing: The link between internal and external procedural justice. Police Quarterly, 20(1): 3-23. https://doi.org/10.11 $\underline{77 / 1098611116657818}$ 
[12] Whitton, J., Brasier, K., Charnley-Parry, I., Cotton, M. (2017). Shale gas governance in the United Kingdom and the United States: Opportunities for public participation and the implications for social justice. Energy Research \& Social Science, (26): 11-22. https://doi. org/10.1016/j.erss.2017.01.015

[13] Magalhaes, P. C., Aguiar-Conraria, L. Procedural fairness, the economy, and support for political authorities. Political Psychology, 40(1): 165-181. https://doi.org/10.1111/pops.1 $\underline{2500}$

[14] Esaiasson, P., Persson, M., Gilljam, M., Lindholm, T. (2019). Reconsidering the Role of Procedures for Decision Acceptance. British Journal of Political Science, 49(1): 291-314. https://doi.org/10.1017/S0007123416000508

[15] Niesiobedzka, M., Kolodziej, S., The fair process effect in taxation: the roles of procedural fairness, outcome favorability and outcome fairness in the acceptance of tax authority decisions. Current Psychology, 39(1): 246-253. https://doi.org/10.1007/s12144-017-9762-x

[16] Geraci, A., Surian, L. (2011). The developmental roots of fairness: infants' reactions to equal and unequal distributions of resources. Developmental Science, 14(5): 1012-1020. https://doi.org/10.1111/j.1467-7687.2011.01048.x

[17] Sloane, S., Baillargeon, R., Premack, D. (2012). Do Infants have a sense of fairness. Psychological Science, 23(2): 196-204. https://doi.org/10.1177/0956797611422072

[18] Robbins, J. M., Ford, M. T., Tetrick, L. E. (2012). Perceived unfairness and employee health: a meta-analytic integration. Journal of Applied Psychology, 97(2): 235-272. https:// doi.org/10.1037/a0025408

[19] Shaw, A., Montinari, N., Piovesan, M., Olson, K. R., Gino, F., Norton, M. I. (2014). Children Develop a Veil of Fairness. Journal of Experimental Psychology-General, 143(1): 363-375. https://doi.org/10.1037/a0031247

[20] Maier, C. A., Priest, J. B. (2016). Perceived Fairness, Marital Conflict, and Depression: A Dyadic Data Analysis. American Journal of Family Therapy, 44(2): 95-109. https://doi.or $\mathrm{g} / 10.1080 / 01926187.2016 .1145083$

[21] Starmans, C., Sheskin, M., Bloom, P. (2017). Why people prefer unequal societies. Nature Human Behaviour, 1(4). https://doi.org/10.1038/s41562-017-0082

[22] McAuliffe, K., Blake, P. R., Warneken, F. (2020). Costly fairness in children is influenced by who is watching. Developmental Psychology, 56(4): 773-782. https://doi.org/10.1037/d ev0000888.

\section{$7 \quad$ Authors}

Xiaolei Wang works at the School of Control Engineering belonging to Northeastern University at Qinhuangdao in China

Junchen Wang works at the School of Management in the Northeastern University at Qinhuangdao in China

Zengxin Li works at the Department of Economics in Qinhuangdao Vocational and Technical College China.

Article submitted 2020-05-05. Resubmitted 2020-06-19. Final acceptance 2020-06-22. Final version published as submitted by the authors. 